\title{
sciendo
}

\author{
URSZULA FAŁKOWSKA ${ }^{1}$, AGNIESZKA RADZKA ${ }^{1}$, WANDA DOBRYNIEWSKA ${ }^{1}$, \\ KAROL KRAWIEC ${ }^{1}$, MICHAŁ TCHÓRZ²
}

\section{Evaluation of knowledge of Polish medical students regarding toxic plants}

\begin{abstract}
Introduction. There are approximately 300 species of poisonous plants in Poland. About 50 of them contain toxic substances which pose threat to health when consumed. Accidental poisonings remain the most common cause, but there were also cases correlated to suicidal or criminal purposes. There are only few toxicological departments in Poland keeping the records of plant poisonings, what makes presented data inaccurate.

Aim. The authors decided to evaluate knowledge of Polish medical students regarding toxic plants and symptoms of its intoxication.

Material and methods. The number of 734 online responses from students enrolled in medical studies at 16 different Polish universities were collected and analyzed to draw a conclusion.

Results. As many as $87.6 \%$ of all respondents were in favor of introducing obligatory classes covering the issue of toxic plants. They were also asked to identify plants presented in the pictures. When it comes to $53.1 \%$ of students, they were familiar with Datura stramonium L. Over half of the participants were able to recognize the mild symptoms of intoxication, when $25.9 \%$ linked the poisoning to narcotic sleep. Taxus baccata L. was identified by $86.6 \%$ of the respondents and the majority of them possessed knowledge about the related symptoms. Heracleum sosnowskyi Manden. and Caltha palustris L. were recognized by respectively $94 \%$ and $64 \%$ of the students. As many as $84.1 \%$ of participants knew the effects of Heracleum sosnowskyi Manden intoxication. All correct answers related to this poisoning were chosen by $48.3 \%$ respondents. The results revealed that the symptoms of Caltha palustris L. are unknown to the majority. Atropa belladonna L. was successfully identified by 93.6\%, Galanthus nivalis L. by $55.4 \%$ of the students, with a lower percentage of correct responses related to its intoxication.

Conclusions. Such differentiated knowledge can be the result of both educational variances and personal experience. Polish medical universities should consider introducing extra classes that would cover the issue of toxic plant intoxications.
\end{abstract}

Keywords: toxic plants, intoxication, toxicology, knowledge assessment.

DOI: $10.2478 /$ pjph-2018-0004

\section{INTRODUCTION}

Currently, there are approximately 300 species of poisonous plants in Poland. About 50 of them contain toxic substances which, when consumed, pose threat to health and human life [1]. Poisonous plants are often wrongly considered to be harmless to humans. Many victims tend not to report intoxications, even after developing severe symptoms. The numbers of registered cases differ significantly, depending on the source. According to Chief Sanitary Inspectorate by the National Institute of Public Health, in the years 2007-2016 in Poland 66 people in total [1-11] suffered from plant poisoning with the percentage of hospitalizations ranging from $55.6 \%$ to $100 \%$ [1-11]. That can be compared to England, where according to The Handle with Care display at the Harrogate Autumn Flower Show in North Yorkshire about 700 incidents were registered in just two-year period from 2014 to 2015 [12]. The data indicate that different species of plants can be found in different regions of Europe with varying occurrence rate. As for Poland, no cases were registered in 2016 [1], whereas 18 in 2008 [9], which remains a year with the highest number of incidents. In the mentioned time period all regions of the country were affected with four cases being reported and hospitalized in Lublin Voivodeship, one in 2007 [10], two in 2008 [9] and one in 2010 [7]. From that source no data regarding the gender or age of the victims are available. The intoxications seem to be season-independent, which suggests that the poisonings might be from various plants, growing in different times of the year. However, other resources report significantly higher numbers of cases. This can be exemplified by data from the Toxicology Department in Łódź keeping its own records and reporting an average of 10.11 victims per year in the years 2002-2011 [11] and by those from the Institute of Occupational Medicine in Sosnowiec, that suggests an average of 53.4 cases per year in the surrounding area between 2010 and 2016 [12]. This source also proves a worryingly higher number of poisoned

\footnotetext{
${ }^{1}$ Students' Scientific Association at the Chair and Department of Toxicology, Medical University of Lublin, Poland

${ }^{2}$ Chair and Department of Toxicology, Medical University of Lublin, Poland
} 
children in comparison to adults (for instance in the year 2013, 7 adults were hospitalized, comparing to 49 children) [12]. All the cases account for averagely $1.18 \%$ of all poisonings in that area [12]. To compare, according to the American Association of Poison Control Centers (AAPCC) and the Cincinnati-based Drug and Poison Information Center (DPIC), between 2000 and 2011 around $3.4 \%$ of intoxications reported in the United States [13] were caused by plants, proving again that the distribution of toxic herbs on Earth is uneven.

The most common reasons for intoxications in Poland are accidental poisonings and intentional, either suicidal or habitual usage [12]. The notable differences between data from various institutions can be justified by the fact that many doctors do not report the cases or do not keep records of the incidents. This is also due to the fact that it is difficult to fully prove the intoxication to be caused by a plant.

Alarmingly high numbers regarding accidental plant intoxications as well as very high percentage of minor victims might indicate the need for raising social awareness among both adults and children. Currently, Polish educational institutions, apart from certain medical schools, do not conduct any programs related to the issue and the level of knowledge in this field is suspected to be low.

\section{AIM}

Due to the fact that every year at least some new cases are being confirmed, the authors decided to conduct a survey regarding the knowledge about poisonous plants among Polish medical students.

\section{MATERIALS AND METHODS}

The number of 734 online responses from students enrolled in medical studies at 16 different Polish universities were collected and analyzed. Reasonable conclusions were later drawn. Statistical analysis was carried out by Statistica 12 software. Due to the oblique distribution of measurable parameters, the U Mann-Whitney test was used to compare two independent groups. For non-measurable parameters there used the Chisquare homogeneity or independence test $\left(\chi^{2}\right.$ test); $\mathrm{p}<0.05$ was considered as statistically significant.

\section{RESULTS}

As many as 734 respondents from different faculties and years of study at nearly all medical universities in Poland participated in the survey. The group of $75.5 \%$ of the respondents were females and $24.5 \%$ males. The number of $99.2 \%$ of the answerers were aged $18-30$. There were no statistically significant differences between the age of women and men participating in the survey $(Z=0.19 ; \mathrm{p}=0.84)$.

Among the respondents, $18.40 \%$ were confirmed to be students of the Medical University of Lublin. The second largest group $(15.90 \%)$ consisted of students from the Medical University of Bialystok. This group was followed by undergraduates from Medical University of Bydgoszcz, who accounted for $11.6 \%$ of all responses. Less than $1 \%$ of the students were enrolled at the Medical Universities in Wroclaw, Katowice, Olsztyn, Opole and Radom. With regard to the faculty studied, the largest number of replies was from medical students $(53.5 \%)$ followed by future pharmacists $(12.3 \%)$ and dentistry students $(6.7 \%)$. On the contrary, few responses were submitted by students of biomedicine $(0.3 \%)$ and dental techniques $(0.3 \%)$.

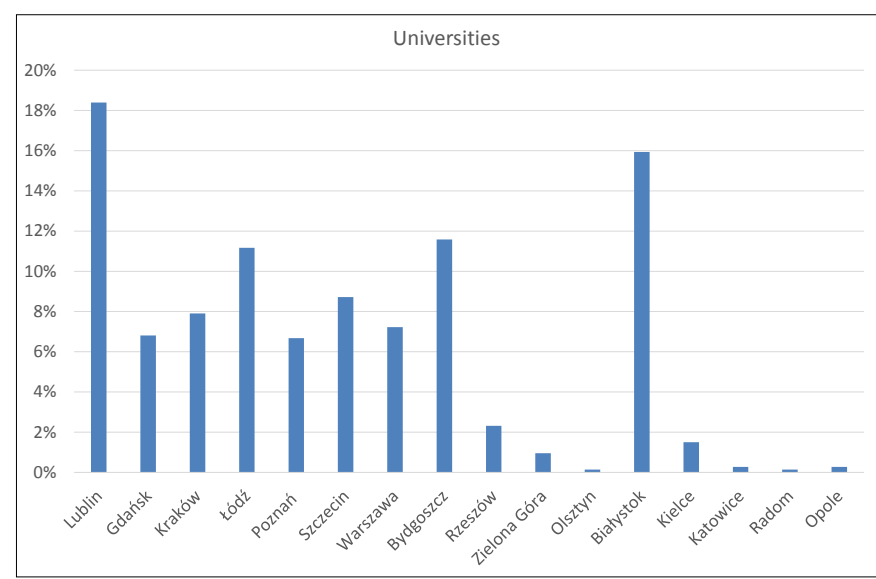

FIGURE 1. Distribution of respondents according to university location.

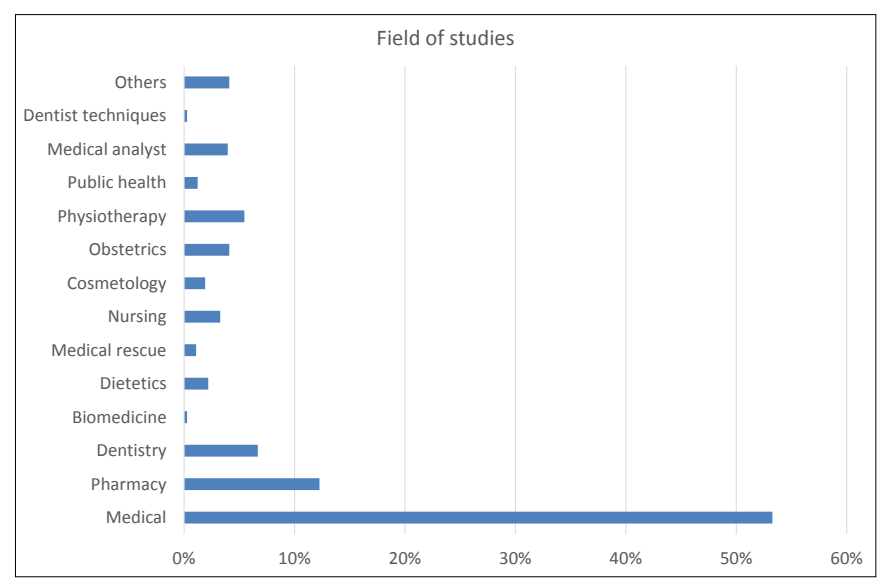

FIGURE 2. Distribution of respondents according to study course.

The group of $52.9 \%$ of the students were presented with the subject of poisonous plants during their classes. Students' answers to the question "Have you ever met with the subject of poisonous plants at the university?" differed statistically significantly depending on the field of study $\left(\chi^{2}=167.20 ; p=0.00\right)$. Discussing the subject of poisonous plants during classes was declared by $\mathrm{n}=185(47.31 \%)$ students of the medical faculty, $\mathrm{n}=87(96.67 \%)$ students of pharmacy, $\mathrm{n}=17(34.69 \%)$ students of dentistry, $n=9(56.25 \%)$ students of dietetics, $n=7(87.5 \%)$ students of medical rescue, $\mathrm{n}=4(47.31 \%)$ nursing students, $\mathrm{n}=9(64.29 \%)$ cosmetology students, $\mathrm{n}=1 \quad(3.33 \%)$ students of obstetrics, $n=3(7.5 \%)$ students of physiotherapy, $n=2$ (22.22\%) students of public health, $n=14$ (48.28\%) students of analytical medicine. None of the students in the field of biomedicine and dental techniques participating in the research met with the subject of poisonous plants in the classroom.

Nonetheless, $86.2 \%$ of all participants believe the issue has not been exhausted, whereas $87.6 \%$ claim that this topic should be part of the curriculum. A detailed statistical analysis revealed that the answer to the question about the appropriateness of conducting such classes in the course of study depends on the field of study $\left(\chi^{2}=43.99 ; p=0.00\right)$. All students of the field of biomedicine, dietetics, medical rescue, public health, dental techniques and the vast majority of students of pharmacy $n=88(97.78 \%)$, nursing $n=23(95.83 \%)$, cosmetology $\mathrm{n}=13(92.86 \%)$, analytical medicine $\mathrm{n}=27(93.10 \%)$, medicine $\mathrm{n}=343(87.72 \%)$ and obstetrics $\mathrm{n}=25(83.33 \%)$ think that such 
classes are needed. On the other hand, $35 \%$ of physiotherapy students $(n=14), 24.49 \%$ of dentistry students $(n=12)$ and $20 \%$ of students of other faculties $(n=6)$ think that such classes are not needed.

Heve you met with the subject of poisonous plants during your studies?

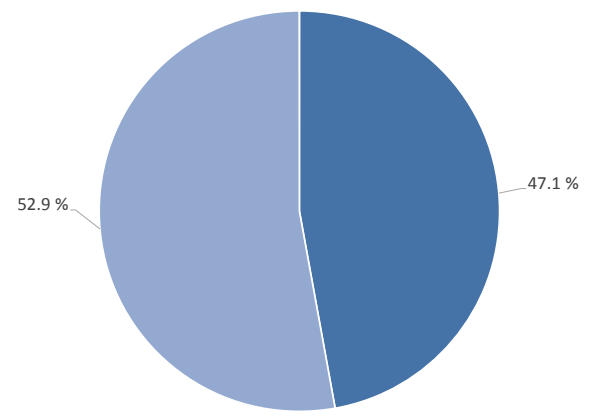

- Yes $m$ No

FIGURE 3. Percentage of respondents who met or did not meet with the subject of poisonous plants during studies.

In the case you had that type of classes, do you think that topic has been presented exhaustively?

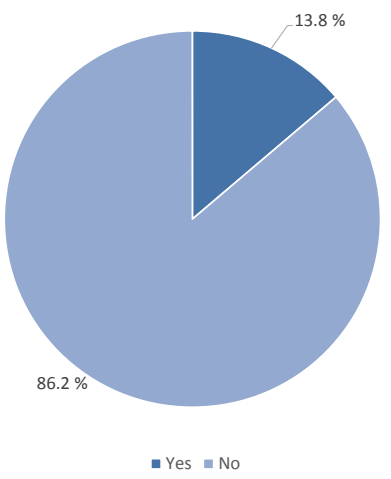

FIGURE 4. Percentage of respondents according to their opinion on the way of presenting the subject of poisonous plants during studies.

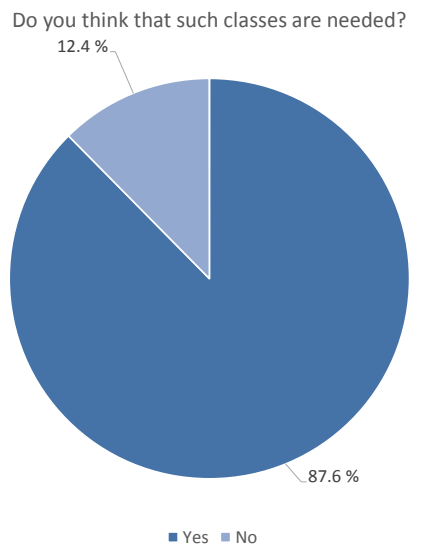

FIGURE 5. Percentage of respondents according to their opinion on the need for classes concerning poisonous plants.

The participants were also asked to identify certain species in the pictures.

The first plant was Datura stramonium L. and only $53.1 \%$ of the answerers were able to distinguish this species from $\mathrm{Ca}$ lystegia sepium (L.) R. Br., Cerastium arvense L. and Corydalis solida (L.) Clairv. The answers given by women and men to question 10 did not differ significantly in statistical terms $\left(\chi^{2}=6.53 ; p=0.09\right)$. As for the second plant, Taxus baccata $\mathrm{L}$.,
$86.8 \%$ of the students selected the correct answer. They were presented with 3 other options, including Juniperus communis L. Taxus $\times$ media Rehder and Tanacetum vulgare L. There were significant differences in the answers given to identify Taxus baccata L. by women and men $\left(\chi^{2}=9.14 ; \mathrm{p}=0.03\right)$. Males recognized: Taxus baccata L. n=168 (93.33\%), Juniperus communis L. $\mathrm{n}=7$ (3.89\%), Taxus $\times$ media Rehder $\mathrm{n}=3$ (1.67\%), Tanacetum vulgare L. $\mathrm{n}=2(1.11 \%)$. The women answered Taxus baccata L. n=469 (84.66\%), Juniperus communis L. $\mathrm{n}=53$ (9.5\%), Taxus $\times$ media Rehder $\mathrm{n}=15(2.71 \%)$, and Tanacetum vulgare L. $\mathrm{n}=17$ (3.07\%). The next question regarded Heracleum sosnowskyi Manden. This species had to be differentiated from Plantago major L., Anethum graveolens L. and Arctium lappa L. and in this case, $94 \%$ of all participants identified the plant correctly. Answers given by women and men to identify Heracleum sosnowskyi Manden. did not differ significantly in statistical terms $\left(\chi^{2}=3.75 ; p=0.29\right)$. Unfortunately, in the next question only $64 \%$ of the respondents possessed sufficient knowledge to distinguish Caltha palustris L. from Ranunculus acris L., Ficaria verna Huds. and Anemone nemorosa L. Answers given by women and men to identify Caltha palustris L. did not differ significantly in statistical terms $\left(\chi^{2}=4.23 ; \mathrm{p}=0.24\right)$. Later on however, the vast majority of the answerers (93.6\%) were familiarized with the appearance of Atropa belladonna L., whereas the rest believed the plant was Aronia melanocarpa (Michx.) Elliott, Vaccinium myrtilloides Michx. or Sambucus nigra L. Answers given by women and men to identify Atropa belladonna L. did not differ significantly in statistical terms $\left(\chi^{2}=3.00 ; \mathrm{p}=0.39\right)$.

The species presented in the last picture was Galanthus nivalis $\mathrm{L}$. and here, $55.4 \%$ of the students selected the proper option, having to differentiate the plant from three other: Campanula isophylla Moretti, Convallaria majalis L. and Primula obconica Hance. Answers given by women and men to identify Galanthus nivalis L. did not differ significantly in statistical terms $\left(\chi^{2}=5.14 ; p=0.16\right)$.

Taking into consideration the fact that pharmacy students have classes of pharmaceutical botany in the curriculum, their knowledge was compared with the students of other faculties.

There were statistically significant differences in the answers given to identify Datura stramonium L. by pharmacy students and other faculties involved in the survey $\left(\chi^{2}=25.04\right.$; $\mathrm{p}=0.00002)$. Students of pharmacy recognized Datura stramonium L. $\mathrm{n}=70$ (77.78\%), Calystegia sepium (L.) R.Br. $\mathrm{n}=16$ (17.78\%), Corydalis solida (L.) Clairv. $\mathrm{n}=2$ (2.22\%), Cerastium arvense $\mathrm{L} . \mathrm{n}=2(2.22 \%)$. Students of the other faculties in the same illustration recognized Datura stramonium $\mathrm{L}$. $\mathrm{n}=320$ (49.69\%), Calystegia sepium (L.) R.Br. n=265 (41.15\%), Corydalis solida (L.) Clairv. $\mathrm{n}=8(4.35 \%)$, Cerastium arvense L. $n=31(4.81 \%)$. There were statistically significant differences in the answers given to identify Galanthus nivalis L. by pharmacy students and other faculties involved in the survey $\left(\chi^{2}=9.05 ; p=0.03\right)$. Students of pharmacy recognized Galanthus nivalis $\mathrm{L} . \mathrm{n}=62$ (68.89\%), Convallaria majalis $\mathrm{L} . \mathrm{n}=13$ (14.44\%), Campanula isophylla Moretti. $\mathrm{n}=9$ (10\%), Primula obconica Hance $n=6(6.67 \%)$. Students of the other faculties in the same illustration recognized Galanthus nivalis L. $\mathrm{n}=345$ (53.57\%), Convallaria majalis L. $\mathrm{n}=109$ (16.93\%), Primula obconica Hance $\mathrm{n}=104$ (16.15\%), Campanula isophylla Moretti $n=86$ (13.35\%). Answers to the questions regarding the identification of other plants did not differ significantly between the students of pharmacy and other fields of study. 
TABLE 1. Percentage of respondents who correctly recognised poisonous plants.

\begin{tabular}{|c|c|c|}
\hline Plant to recognize & $\begin{array}{l}\text { Quantity of } \\
\text { correct } \\
\text { responses }\end{array}$ & Choosing between: \\
\hline Datura stramonium L. & $53.1 \%$ & $\begin{array}{l}\text { Calystegia sepium (L.) R. Br., } \\
\text { Cerastium arvense L., } \\
\text { Corydalis solida (L.) Clairv. }\end{array}$ \\
\hline Taxus baccata $\mathrm{L}$. & $86.8 \%$ & $\begin{array}{l}\text { Juniperus communis L., } \\
\text { Taxus } \times \text { media Rehder, } \\
\text { Tanacetum vulgare L. }\end{array}$ \\
\hline $\begin{array}{l}\text { Heracleum sosnowskyi } \\
\text { Manden }\end{array}$ & $94 \%$ & $\begin{array}{c}\text { Plantago major L., } \\
\text { Anethum graveolens L., } \\
\text { Arctium lappa L. }\end{array}$ \\
\hline Caltha palustris L. & $64 \%$ & $\begin{array}{l}\text { Ranunculus acris L., } \\
\text { Ficaria verna Huds., } \\
\text { Anemone nemorosa L. }\end{array}$ \\
\hline Atropa belladonna L. & $93.6 \%$ & $\begin{array}{c}\text { Aronia melanocarpa (Michx.) Elliott, } \\
\text { Vaccinium myrtilloides Michx., } \\
\text { Sambucus nigra L. }\end{array}$ \\
\hline Galanthus nivalis $\mathrm{L}$. & $55.4 \%$ & $\begin{array}{c}\text { Campanula isophylla Moretti, } \\
\text { Convallaria majalis L., } \\
\text { Primula obconica } \text { Hance. }\end{array}$ \\
\hline
\end{tabular}

To verify the knowledge regarding the symptomatology of plant intoxications, we asked the participants to select the symptoms of poisoning with certain species. The first question was about Datura stramonium L. The results are presented in Table 2 and the related symptoms included pupil dilation, dry and red skin, hallucinations and narcotic sleep.

TABLE 2. Percentage of respondents who correctly recognised symptoms of Datura stramonium L. poisoning.

\begin{tabular}{lc}
\hline \hline $\begin{array}{c}\text { Combinations of symptoms } \\
\text { - the possible answers }\end{array}$ & $\begin{array}{c}\text { Participants who chose } \\
\text { the answer (percent of total } \\
\text { amount of respondents) }\end{array}$ \\
\hline Narrow pupils, pale and wet skin & $32.2 \%$ \\
\hline Pupil dilation, dry and red skin & $60.3 \%$ \\
\hline Hallucinations & $56.9 \%$ \\
\hline Narcotic sleep & $25.9 \%$ \\
\hline
\end{tabular}

The results of the next question, regarding the effects of Taxus baccata L. intoxication, are summarized in Table 3. The symptoms of this particular poisoning are nausea, vomiting, breathing disorders and cardiac disfunction.

TABLE 3. Symptoms of Taxus baccata L. intoxication.

\begin{tabular}{lc}
\hline $\begin{array}{c}\text { Combinations of symptoms } \\
\text { - the possible answers }\end{array}$ & $\begin{array}{c}\text { Participants who chose } \\
\text { the answer (percent of total } \\
\text { amount of respondents) }\end{array}$ \\
\hline Nausea, vomiting & $67.6 \%$ \\
\hline Breathing disorders, cardiac dysfunction & $72.9 \%$ \\
\hline Excitation & $18.4 \%$ \\
\hline Increase in blood pressure & $33.2 \%$ \\
\hline
\end{tabular}

The third question concerned Heracleum sosnowskyi Manden. poisoning and offered a variety of options which are presented in Table 4.

TABLE 4. Symptoms of Heracleum sosnowskyi Manden. intoxication.

\begin{tabular}{lc}
\hline $\begin{array}{c}\text { Combinations of symptoms } \\
\text { - the possible answers }\end{array}$ & $\begin{array}{c}\text { Participants who chose } \\
\text { the answer (percent of total } \\
\text { amount of respondents) }\end{array}$ \\
\hline Second and third degree burns & $85.4 \%$ \\
\hline $\begin{array}{l}\text { Reddening of the skin, formation of } \\
\text { blisters with serous fluid }\end{array}$ & $84.6 \%$ \\
\hline It is called "Revenge of Stalin" & $55.3 \%$ \\
\hline Inflammation usually lasts for 3 days & $16.2 \%$ \\
\hline
\end{tabular}

As for the next question, it was related to Caltha palustris L. poisoning. In this case, the respondents should have chosen allergic reaction of the skin, nausea and bloody vomiting, polyuria. All the results are included in Table 5.

TABLE 5. Symptoms of Caltha palustris L. intoxication.

\begin{tabular}{lc}
\hline \multicolumn{1}{c}{$\begin{array}{c}\text { Combinations of symptoms } \\
\text { - the possible answers }\end{array}$} & $\begin{array}{c}\text { Participants who chose } \\
\text { the answer (percent of total } \\
\text { amount of respondents) }\end{array}$ \\
\hline Allergic reaction of the skin & $47 \%$ \\
\hline Nausea and bloody vomiting & $49.2 \%$ \\
\hline Constipation & $20.2 \%$ \\
\hline Polyuria & $31.2 \%$ \\
\hline
\end{tabular}

Table 6 summarizes the results of the next question, which verified the knowledge about Atropa belladonna L. poisoning. Among other options, the correct ones in this case were: strong excitation/simulation, euphoric hallucinations, photophobia, speech disorders, respiratory failure, coma in the final stage.

TABLE 6. Symptoms of Atropa belladonna L. intoxication.

\begin{tabular}{lc}
\hline \multicolumn{1}{c}{$\begin{array}{c}\text { Combinations of symptoms } \\
\text { - the possible answers }\end{array}$} & $\begin{array}{c}\text { Participants who chose } \\
\text { the answer (percent of total } \\
\text { amount of respondents) }\end{array}$ \\
\hline $\begin{array}{l}\text { Disorders of consciousness, dullness, } \\
\text { slowing down }\end{array}$ & $44.6 \%$ \\
\hline $\begin{array}{l}\text { Strong excitation/simulation, euphoric } \\
\text { hallucinations }\end{array}$ & $54 \%$ \\
\hline Photophobia, speech disorders & $54.1 \%$ \\
\hline $\begin{array}{l}\text { Respiratory failure, coma in the final } \\
\text { stage }\end{array}$ & $63.4 \%$ \\
\hline
\end{tabular}

The last question regarded symptomatology of Galanthus nivalis L. poisoning. The results are presented in Table 7. All of the answers included the affects of this particular intoxication.

TABLE 7. Symptoms of Galanthus nivalis L. intoxication.

\begin{tabular}{lc}
\hline $\begin{array}{c}\text { Combinations of symptoms } \\
\text { - the possible answers }\end{array}$ & $\begin{array}{c}\text { Participants who chose } \\
\text { the answer (percent of total } \\
\text { amount of respondents) }\end{array}$ \\
\hline Diarrhoea and vomiting & $50.7 \%$ \\
\hline Dyspnoea and drooling & $53.1 \%$ \\
\hline Narrow pupils & $27.1 \%$ \\
\hline Drop in blood pressure & $45.8 \%$ \\
\hline
\end{tabular}

\section{DISCUSSION}

The research revealed that less than half of the respondents were presented with the topic of toxic plants as a part of their curriculum. Moreover, the vast majority of the students believe the issue has not been exhausted and should therefore be extended. In general, the knowledge of medical students regarding poisonous plants is limited, however in certain cases it appeared to be surprisingly high. This proves that the study program should either be modified or simply extended. The classes could be introduced as optional mode, helping those who expressed their need to acquire basic knowledge related to this field.

The best known species are Heracleum sosnowskyi Manden., Atropa belladonna L. and Taxus baccata L. The plants were 
successfully identified by respectively $94 \%, 93.6 \%$ and $86.8 \%$ of the respondents. Such awareness may result from raising popularity of Heracleum sosnowskyi Manden. on the Internet as we can often learn about new incidents and the aftermath of such poisoning. Heracleum sosnowskyi Manden. was originally brought to Poland for business purposes as it could be cultivated as a silage plant. For many years it had been generating large economic profits at the State Agricultural Farms in Poland. Although this type of farming no longer exists, Heracleum sosnowskyi Manden. can still be found all around the country, as it easily proliferated from breeding areas to forests and urban open space. Another reason for such advanced knowledge might be that Atropa belladonna L. is a species covered by the pharmacology program at many universities. The respondents may meet patients suffering from Atropa belladonna $\mathrm{L}$. intoxication in their future career, mainly due to the fact that the plant is often mistaken for blueberries and therefore, the results in this case are more than satisfactory. The authors also suspect that such knowledge related to Taxus baccata L. may result from the fact that the plant is often presented to pupils at the early stage of education. The remaining plants were successfully identified by over half of the respondents. Such high percentage of wrong answers suggests that the students do not pay sufficient attention to naming. Moreover, they might have difficulties memorizing characteristic features unique to each plant. The results may also infer from improper selection of study material as well as from low-quality of imaging.

\section{Datura stramonium L.}

Currently, we do not observe incidents of suicidal intoxications as well as those resulting from attempted murders. However, more poisoning cases are registered due to recreational use of Datura stramonium L. seeds. Thus, it is extremely important for a future doctor to correctly recognize the symptoms of alleged intoxications [14]. Individuals who experiment with this plant tend to use social media platforms as means of communication with other users [15]. A study conducted in 2008 by the National Bureau For Drug Prevention revealed that many young people intentionally consume Datura stramonium L. plants [16], whereas a report prepared in 2011 by the General Police Headquarters of Poland proved Datura stramonium L. to be one of the most popular intoxicant plants favored by Polish teenagers [17]. Taking into consideration these statistical data it is disturbing that $32.3 \%$ of students selected incorrect symptoms in our survey. Moreover, only $25.9 \%$ of all participants are aware of the fact that this type of poisoning may lead to narcotic sleep. All parts of the plant are toxic. Still, the most dangerous and, unfortunately, popular, are brown-black seeds enclosing fructifications that include tropane alkaloids such as atropine, hyoscyamine and scopolamine. Those are responsible for hallucinations deriving from serious disruption of parasympathetic nervous system [18-21].

\section{Taxus baccata $\mathrm{L}$.}

The most common intoxication results from consumption of decoction of taxus needles, that is sometimes used by women for abortive purposes. Taxine alkaloids can be found in yew plants. Although they have been proven to have cardio- and hepatotoxic properties, the exact mechanism of action remains unknown. Our study showed that $72.9 \%$ of the students were able to identify breathing disorders and cardiac dysfunction as possible symptoms of intoxication. Moreover, $67.6 \%$ of the respondents can link the poisoning with nausea and vomiting. Future doctors may be asked to treat small children, who tend to chew the tops of plant branches as well as the seeds and therefore, may be subject to intoxication. Among 24 children hospitalized in the years 2010-2014 due to unintentional plant intoxication in Rzeszow, the largest number of them (5) were diagnosed with taxus poisoning [22]. The suicidal consumptions of decoction of taxus bark or needles are also occasionally registered [23].

\section{Heracleum sosnowskyi Manden.}

Originally Heracleum sosnowskyi Manden. was grown in Caucasia to feed domesticated livestock. As the plant quickly showed high resistance to environmental changes, it gained popularity within the Near East in the middle of the XX century. The species first appeared in Poland in 1958 and was never cultivated for feeding purposes, mainly due to availability of other fodders. However, it quickly distributed around the country. This was mainly due to its adaptation capacity, which caused the plant to proliferate, posing a real threat for the society. In many regions of Poland and other countries of Central Europe it remains a serious problem, becoming a matter of international concern [24]. Heracleum sosnowskyi Manden. is easily accessible and cheap to cultivate, therefore it is currently used as a component of chemical substances. This can contribute to increased control of unrestrained grow of the species [25]. Unfortunately, it is extremely dangerous to humans due to fragrant furanocoumarins present in its leaves and stem. Those, in the presence of UV light, cause II and III degree photodermatosis of human skin. This condition is referred to as severe and can be considered a serious threat when affecting more than $20 \%$ of skin surface. In Poland no statistical data can be obtained with regard to Heracleum sosnowskyi Manden. burns. However, it can be observed that most of the cases are reported within rural areas of southeastern Poland [26]. One should not forget that the toxins present in Sosnowsky's hogweed can cause burns also within the respiratory tract. The majority of incidents regard children [27]. Fortunately, the level of social awareness can be assessed as moderate. As for our survey, $84.1 \%$ of the respondents were able to identify certain symptoms of the burn, whereas $48.3 \%$ selected all the correct answers. In general, individuals who live in the areas with high prevalence of the species seem to possess sufficient knowledge to recognize the plant. It is characterized by wide feathery leaves (diameter exceeding $1.5 \mathrm{~m}$ ), big white umbels and it can reach up to $4-5 \mathrm{~m}$. Due to unusual size the burns are less and less often observed [28].

\section{Caltha palustris $\mathbf{L}$.}

Marsh-marigold remains a plant native to Northern Hemisphere. It occurs within wetlands, mainly bogs, close to wastewater sources. In the urban areas it is often cultivated as ornamental plant, serving as a decoration. Producing rhizomes and buds, it eventually grows characteristic yellow flowers. The rhizome and stem of the plant contain a group of potentially dangerous alkaloids, with protoanemonin identified as being the most harmful one [29]. Excessive consumption of toxic elements of Caltha palustris L. can lead to dysphagia, burning sensation within the throat, gastritis, vomiting, diarrhea, convulsions, dizziness, fainting and polyuria. Direct contact of protoanemonin with the skin may cause blisters and acute or 
chronic inflammation [30]. There is one natural antidote, identified as dienelactone hydrolase, which is isolated from Pseudomonas spp. [31]. However, due to extreme rareness of Caltha palustris L. intoxications this enzyme is not produced on a daily basis. Although the poisonings are uncommon, $46.1 \%$ of all respondents successfully recognized the symptoms in our survey. Research is currently being done trying to determine the possible influence of Caltha palustris L. -derived polysaccharide $\mathrm{B}$ on treatment of collagen-induced arthritis (CIA) and other types of colagenosis. The experiments conducted on mice show promising results [32].

\section{Atropa belladonna L.}

The plant is also called the deadly nightshade. Nearly all of its parts contain alkaloids such as atropine, hyoscyamine and scopolamine. The root however, considered to be the most toxic part, is also a site of storage for apoatropine and belladonine, with the last one demonstrating synergic effect with regard to hyoscyamine. What can be inferred, affecting the intestines and the eye, the root shows 12 times stronger parasympatholytic action than the leave itself. In large doses, both atropine and hyoscyamine act as stimulants within the central nervous system, whereas in small amounts they paralyse the peripheral nervous system. Consumption of Atropa belladonna L. can be related to symptoms of acute psychosis. In clinical practice, any intoxication with this particular plant is considered a poisoning [33]. The deadly dose for adults is estimated to be equal to consumption of 10-20 fruits. For children, even 3-4 fruits can lead to the individual's death [33]. The literature confirms one case of a 9-year-old boy who, having eaten 20-25 berries, became seriously intoxicated and later developed symptoms of acute psychosis. The child was successfully treated with intravenous administration of physostigmine [34]. In general, the alkaloids present in Atropa belladonna L. serve as neuromuscular blocking agents and may lead to the paralysis of respiratory tract [34]. Usually, the intoxication can be characterized by excitation, hallucinations, convulsions, and myoclonus. It may also result in pupil dilation and therefore, photophobia or sensation of blindness. Over half of the respondents possessed sufficient knowledge to identify the effects of intoxication with Atropa belladonna L. Strong excitation and euphoric hallucinations were selected by $54 \%$ of the students, whereas photophobia and speech disorders by $54.1 \%$. As many as $63.5 \%$ of the participants are aware that this poisoning may lead to respiratory failure and coma. As this species remains the most common reason for plant intoxication in children, it is worrying that $44.6 \%$ of future doctors consider consciousness disorders, dullness and general slowdown to be caused by Atropa belladonna L. consumption. Studies reveal also a certain number of unintentional intoxications in adults, however, the plant is rarely used for criminal purposes. Poisonings related to consumption of tropane containing pharmaceutics are more common recently [33].

\section{Galanthus nivalis L.}

Naturally occurring all around the Europe, the snowdrop can serve as ornamental plant and is gaining popularity in Poland. Nonetheless, in certain countries is has been listed as endangered species. The blossom period starts between February and April, making the plant a common symbol of early spring. The tubers reach up to $20 \mathrm{~mm}$ and contain large amounts of phenanthrene alkaloids, the most dangerous ones among all types of chemical present in various parts of this plant. As for the statistical data regarding the number of incidents, no research has been done yet. However, some poisoning cases have been observed among cattle and humans. The most common symptoms of Galanthus nivalis L. intoxication involve hypersalivation, vomiting, severe abdominal pain, diarrhea, impaired coordination and balance, as well as convulsions, hypotension and tachycardia. In our survey, $30.1 \%$ of all respondents identified the symptoms correctly. Galanthus nivalis L. plays a significant role in pharmaceutical industry as galantamine, present in the species, may serve as a natural anti-acetylcholinesterase [35]. The plant is also widely used in biotechnology, being a substrate for lecithin production and therefore, enabling retroviral inhibition [36].

\section{CONCLUSIONS}

The overall knowledge of Polish medical students in regard to poisonous plants can be assessed as moderate. The survey showed that the university course programs tend to be selective in deciding which species to include in the obligatory courses. Moreover, although the majority of the students admit to never have been taught about these types of plants, in the second part of the survey all of the species were correctly recognized by over half of the respondents. This can lead to a conclusion that in many cases the knowledge required to answer a certain question can be gained from personal experience rather than from the university course. Social awareness, popularity of the species within the social media platforms as well as individual interests contribute to this type of experience. As for the age of the participants, it can be seen that it varied between students and although a higher number of responses has been submitted from those who already started their clinical years, there is still a notable number of replies from freshmen or pre-clinical students. Hence, it must be taken into consideration that some of the respondents could not have a chance to study the issue yet.

Independently from the results of the survey, the statistical data regarding the number of plant poisoning incidents in Poland clearly indicate that this remains a current problem in our country. Throughout the past ten years, the cases were reported in all regions, during all seasons of the year and involved victims of all ages. As for the survey, the vast majority of the respondents expressed their need to extend their knowledge in the field of plant toxicology. Both statistical data and the results of the questionnaire can be the reason to introduce obligatory classes covering the issue of poisonous plants.

Searching for the areas for improvement in this field, it is worth mentioning that the topic of toxic plants should either be re-approached or extended in medical schools. This can be justified by the case of Atropa belladonna L., where almost all of the participants were skilled enough to recognize the species in the picture, while nearly half of them identified the symptoms of intoxication incorrectly. Undoubtedly, many factors contributed to such results, but such a big difference in the percentage of correct answers within these two questions might suggest that the issue, although covered by the program, has not been exhausted during the classes. One should not forget that Atropa belladonna L. remains the most common reason for plant intoxication among children in Poland. Thus, it is of highest importance to familiarize students from our 
country with this dangerous plant. Also, when comparing data obtained from questions regarding Datura stramonium L., it turned out that about half of the students were familiar with the species in terms of its appearance and even fewer with the symptoms of poisoning. Unfortunately, this particular species continues gaining occasional users, mainly due to its hallucinating properties and, as indicated by the results, Polish medical schools seem not to present their students with this plant. The university authorities responsible for the course programs should keep that in mind when re-approaching the issue.

\section{REFERENCES}

1. Pach J. Zarys toksykologii klinicznej. Kraków: Wydawnictwo Uniwersytetu Jagiellońskiego; 2009. p.574-94.

2. National Institute of Public Health [Internet]. Infectious diseases and poisonings in Poland in 2016. [cited 2018 May 20]. Available from: http:// wwwold.pzh.gov.pl/oldpage/epimeld/2016/Ch_2016.pdf.

3. National Institute of Public Health [Internet]. Infectious diseases and poisonings in Poland in 2015. [cited 2018 May 20]. Available from: http:// wwwold.pzh.gov.pl/oldpage/epimeld/2015/Ch_2015.pdf.

4. National Institute of Public Health [Internet]. Infectious diseases and poisonings in Poland in 2014. [cited 2018 May 20]. Available from: http:// wwwold.pzh.gov.pl/oldpage/epimeld/2014/Ch 2014.pdf.

5. National Institute of Public Health [Internet]. Infectious diseases and poisonings in Poland in 2013. [cited 2018 May 20]. Available from: http:// wwwold.pzh.gov.pl/oldpage/epimeld/2013/Ch_2013.pdf.

6. National Institute of Public Health [Internet]. Infectious diseases and poisonings in Poland in 2012. [cited 2018 May 20]. Available from: http:// wwwold.pzh.gov.pl/oldpage/epimeld/2012/Ch 2012.pdf.

7. National Institute of Public Health [Internet]. Infectious diseases and poisonings in Poland in 2011. [cited 2018 May 20]. Available from: http:// wwwold.pzh.gov.pl/oldpage/epimeld/2011/Ch_2011.pdf.

8. National Institute of Public Health [Internet]. Infectious diseases and poisonings in Poland in 2010. [cited 2018 May 20]. Available from: http:// wwwold.pzh.gov.pl/oldpage/epimeld/2010/Ch_2010.pdf.

9. National Institute of Public Health [Internet]. Infectious diseases and poisonings in Poland in 2009. [cited 2018 May 20]. Available from: http:// wwwold.pzh.gov.pl/oldpage/epimeld/2009/Ch_2009.pdf.

10. National Institute of Public Health [Internet]. Infectious diseases and poisonings in Poland in 2008. [cited 2018 May 20]. Available from: http:// wwwold.pzh.gov.pl/oldpage/epimeld/2008/Ch_2008.pdf.

11. National Institute of Public Health [Internet]. Infectious diseases and poisonings in Poland in 2007. [cited 2018 May 20]. Available from: http:// wwwold.pzh.gov.pl/oldpage/epimeld/2007/Ch_2007.pdf.

12. BBC News [Internet]. Deadly plants on display at Harrogate Flower Show. [cited 2018 May 20]. Available from: http://www.bbc.com/news/uk-england-york-north-yorkshire-37375218.

13. Piekarska-Wijatkowska A, Czyżewska S, Kotwica M, Krakowiak A. Epidemiology of acute poisonings during 2002-2011 in Toxicology Unit: Department of Occupational Medicine and Toxicology, Nofer Institute of Occupational Medicine, Lodz, Poland. Prz Lek. 2013;70(10):848-51.

14. Boroń M, Pawlas N. Poisons caused by poisonous plants and venomous animals in the years 2010-2016 in the Silesia Voivodeship. Environ Med. 2017;20(4):14-20.
15. Petersen DD. Common plant toxicology: A comparison of national and Southwest Ohio data trends on plant poisonings in the 21 st century. Toxicol Appl Pharmacol. 2011;254(2):148-53.

16. Herbert M, Jagiełło Wójtowicz E. Znajomość roślin trujących na przestrzeni wieków. Farm Przgl Nauk, 2009;6:47-50.

17. Neurogroove [Internet]. Bieluń dziędzierzawa. [cited 2018 May 20]. Available from: https://neurogroove.info/tagi/natura/bielu-dzi-dzierzawa.

18. Centrum Informacji o Narkotykach i Narkomanii [Internet]. Młodzież zagrożona wykluczeniem społecznym a używanie substancji psychoaktywnych. [cited 2018 May 20]. Available from: http://www.cinn.gov.pl/ portal?id $=166545$.

19. Statystyka Policji [Internet]. Informacja z działań Policji w zakresie zapobiegania przestępczości oraz patologiom społecznym w 2010 roku. [cited 2018 May 20]. Available from: www.policja.pl/download/1/91190/Raport2011.pdf.

20. Majdanik S, Potocka-Banaś B, Borowiak K. Rzadki przypadek ekspozycji na naturalne środki psychoaktywne i trudności w opiniowaniu sądowolekarskim. An Acad Med Stet. 2013;59(1):58-60.

21. Karadaş S, Selvi Y, Şahin M, et al. Datura stramonium intoxication: report of a case with psychiatric symptoms. J Psychiatr Neurol Sci. 2011;24:152-

22. Demir A, Bagci Taylan S, et al. Case report of delirium related intoxication of Datura stramonium. Int J Mevlana Med Sci. 2013;1(3):42-3.

23. Adegoke SA, Alo LA. Datura stramonium poisoning in children. Niger J Clin Pract. 2013;16(1):116-8.

24. Owsianik D. Analiza zatruć dzieci hospitalizowanych w latach 2010-2014 w Szpitalu Wojewódzkim Nr 2 w Rzeszowie. Wydział Medyczny Uniwersytetu Rzeszowskiego, praca doktorska. Rzeszów; 2016. p. 40-1.

25. Kuliński W, Haładyna W, Leśniewski P. Problems of physical rehabilitation in serious yew poisoning. Baln Pol. 2005;1-2:45-8.

26. Wrzesińska D. Barszcz Sosnowskiego (Heracleum sosnowskyi Manden) - inwazyjny chwast i metody jego zwalczania. Post Nauk Rol. 2006;53(3):39-50.

27. Tomaszkiewicz-Potępa A, Vogt O. Biologically active compounds from Sosnowski's hogweed (Heracleum Sosnowsky Manden). Przem Chem 2010;89(7):973-7.

28. Sachajdakiewicz I, Mędrzycki P. Barszcz olbrzymi. Cz. II. Prz Komunalny. 2008;12:80-2.

29. PubChem Open Chemistry Database [Internet]. Protoanemonin. [cited 2018 May 20]. Available from: https://pubchem.ncbi.nlm.nih.gov/compound/Protoanemonin\#section=Top.

30. Lady Bird Johnson Wildflower Center [Internet]. Caltha palustris var. palustris. [cited 2018 May 20]. Available from: https://www.wildflower. org/plants/result.php?id plant=CAPAP6.

31. Brückmann M, Blasco R, Timmis KN, Pieper DH. Detoxification of protoanemonin by dienelactone hydrolase. J Bacteriol. 1998;180(2):400-2.

32. Suszko A, Obmińska-Mrukowicz B. Influence of polysaccharidefractionsisolated from Caltha palustris L. on the cellularimmuneresponse in collagen-inducedarthritis (CIA) in mice. A comparison with methotrexate. J Ethnopharmacol. 2013;145(1):109-17.

33. Baza roślin [Internet]. Atropa belladonna. [cited 2018 May 20]. Available from: http://aztekium.pl/plants.py?tekst=atropa_belladonna\&lang=pl\&kod=.

34. Lange A. Toft P. Poisoning with nightshade, Atropa belladonna. Ugeskr Laeger. 1990;152(15):1096.

35. Kowal NM, Ahring PK, Liao VWY et al. Galantamine is not a positive allosteric modulator of human $\alpha 4 \beta 2$ or $\alpha 7$ nicotinic acetylcholine receptors. Br J Pharmacol. 2018;18.

36. Couty A, Poppy GM. Does host-feeding on GNA-intoxicated aphids by Aphelinus abdominalis affect their longevity and/or fecundity? Entomol Exp Appl. 2001;100:271-363.

\section{Corresponding author}

Michał Tchórz

Chair and Department of Toxicology

Medical University of Lublin

tel.: 609230296

E-mail: tchorz.michal@gmail.com 